Cahiers du MONDE RUSSE

\section{Cahiers du monde russe}

Russie - Empire russe - Union soviétique et États indépendants

$56 / 2-3 \mid 2015$

Communiquer en URSS et en Europe socialiste

\title{
Electronic Battlefields, Visions of Progress and Computer Networks in State Socialist Poland
}

Champs de bataille électroniques, visions du progrès et réseaux informatiques en Pologne socialiste

\section{Patryk Wasiak}

\section{(2) OpenEdition}

Journals

Édition électronique

URL : http://journals.openedition.org/monderusse/8196

DOI : $10.4000 /$ monderusse.8196

ISSN : 1777-5388

Éditeur

Éditions de l'EHESS

Édition imprimée

Date de publication : 17 avril 2015

Pagination : 495-516

ISBN : 978-2-7132-2476-8

ISSN : $1252-6576$

Référence électronique

Patryk Wasiak, «Electronic Battlefields, Visions of Progress and Computer Networks in State Socialist Poland », Cahiers du monde russe [En ligne], 56/2-3 | 2015, mis en ligne le 17 novembre 2019, Consulté le 19 avril 2019. URL : http://journals.openedition.org/monderusse/8196 ; DOI : 10.4000/ monderusse.8196

Ce document a été généré automatiquement le 19 avril 2019

(c) École des hautes études en sciences sociales 


\section{Electronic Battlefields, Visions of Progress and Computer Networks in State Socialist Poland}

Champs de bataille électroniques, visions du progrès et réseaux informatiques en Pologne socialiste

Patryk Wasiak

1 This article discusses how the development of computer communication networks in socialist Poland was influenced by imagery of economic, scientific and social progress ${ }^{1}$. I argue that attempts at establishing computerized communications networks were interdependent with imagery of electronic communication as an agent of economic and scientific progress. This imagery was juxtaposed to one of computer networks as, in Paul Edward's phrase, a "closed world" - a closed system of gathering and circulating data in which any intrusion from outside is considered as a hostile act. ${ }^{2}$ While discussing attempts to build computer networks in Poland in the 1970s and 1980s, I show how their possible impact on society, economics, and science entered public understanding of this telecommunication technology. During the two decades discussed in this paper, computer professionals, policy makers, and the scientific community actively influenced the social construction of computer communications. As I demonstrate, both imageries of scientific progress and of a "closed world" had a substantial impact on the emergence of computer networks and the ability of Polish users to access international networks. This paper focuses on two computer networks : economic management systems from the 1970s that included exclusively institutional users, and modem-based communication systems from the 1980s, which enabled network access for private computer users. While discussing both networks, I also show the evolution of a network from a technological infrastructure available only to institutional users to an open system of international communications that could be accessed by individual users of computer modems.

Current scholarship of the social construction of media and telecommunications systems emphasizes the political economy and societal impact of technological infrastructures. ${ }^{3}$ 
This historical case, by contrast, shows how a particular telecommunications system came into being through negotiating the cultural meanings of computer communication itself across the activities of relevant institutions, communities and individuals who actively co-constructed those same computer networks. ${ }^{4}$

In a recent study of the building of transnational material infrastructures in Europe, Alexander Badenoch and Andreas Fickers pointed out a significant drawback of studies of different "networks" such as railroad systems, telecommunications and civilian aviation.

Where the role of such networks is mentioned, it is very often in terms that acknowledge their role in transforming society, but far less often to offer a detailed analysis of the complex and contested processes by which such structures came about. $^{5}$

In other words, scholarly literature to date overwhelmingly focuses on the consequences, not the construction, of transnational network infrastructures. The history of Cold War computer network technologies is embedded in a teleological master narrative of "the history of the Internet" which emphasizes the catchy history of the ARPANET network appropriated by scientists who found peaceful purposes for the same technology. ${ }^{6}$ The basic drawback of such a master narrative is that it is based on a technological deterministic approach grounded in an assumption that networks, once built, influence social change. Vincent Mosco's recent study Digital Sublime successfully challenges such a master narrative and demonstrates what the exploration of historical processes of negotiating computer networks' meanings can tell us about power configurations within the worlds of politics, scientific communities, and societies. ${ }^{7}$ In this article, instead of trying to recount a local "history of the Internet," I show how public understanding of computer networks was embedded in contemporary discussions about improving scientific management of the social economy, opening up to the West, and catching up with recent technological developments.

5 The article is based on a content analysis of computer magazines, documents of state agencies, legislative acts, and testimonies of data communication practitioners. The first section outlines the political and cultural contexts of computer network development during the Cold War. The second section reconstructs Polish discourse towards "automated information transmission systems" in the late 1960s and 1970s. Subsequent sections discuss attempts to develop academic computer networks and attempts to link Polish computer modem users to international "electronic communities."

\section{The cold war and telecommunications networks}

6 Thanks to developments in telecommunications and computer technologies after the Second World War, automated information transfer became widespread, and cybernetics grew popular. In the 1950s, cybernetics played a significant role in providing several new technologies with practical scenarios of their applications for military, scientific and economic purposes. ${ }^{8}$ Edwards, while explaining the nature of the "closed world," discusses how telecommunication networks were considered in the US as military systems dedicated to the gathering and circulation of data. ${ }^{9}$ In this "closed world," any intrusion from the outside would be considered a hostile act.

7 The significance of those computer networks constituting the technical infrastructure of the "closed world," such as SAGE and ARPANET, overshadowed the simultaneous development of several civilian online information services, such as airline reservation 
systems, library catalogues and indexed law and medical databases. ${ }^{10}$ At the same time, top decision makers in centrally planned economies acknowledged the concept of applying computer network technology to social and economic planning. Attempts to use networks in planning in the USSR and Salvador Allende's Chile have been discussed by Slava Gerovich and Eden Medina. ${ }^{11}$ As Gerovich pointed out, despite the demise of the Soviet project of a nationwide network of data centres, computer networks from the 1960s existed in the public imagination as an element of the socialist future which promised better management of state affairs. ${ }^{12}$ Computer networks, as Gerovich and Medina showed, became a constant element in the imagined futures of both capitalism and socialism, along with fibre optics and telecommunications satellites. ${ }^{13}$

In the 1980s computer networks and, more broadly, telecommunications systems, were publicly introduced in a new context as an "electronic battlefield," the precursor to present-day "cyber warfare." This new context was influenced by currents in the US. The development of military and civilian computer networks in the 1980s was accompanied by the rise of the figure of a malevolent computer hacker. The potential dangers of hacking computer systems also triggered discussion of the potential malevolent use of computer networks by Soviet saboteurs, or even as part of World War Three. Such imagery was described in detail in the electronic bulletin The Risks Digest, where Western computer professionals shared their fears :

[...] any sector of society can be destabilized, even completely paralyzed - industry and defense, civil and military communications, logistics and transport, public administration, the entire economy - simply by a couple of keystrokes on a computer terminal, anywhere in the world. We do definitely see this as the electronic battleground of the future, and we definitely see ourselves of being in the process of seizing the high ground for ourselves before the other side can get there. ${ }^{14}$

9 It is interesting to see how the military potential of computer networks was considered on the both sides of the Iron Curtain. In 1988, one of the senior political officers in the Military Political Academy, a university for Polish politruks, outlined recent American technological developments in a lecture :

It is remarkable that in the US today the so-called "electronic battlefield" is considered seriously. The US military command has eight plans for global war and sixty plans for critical operations in which data could be transmitted in a few minutes. And everything with the help of a computer. ${ }^{15}$

As he further claimed, this was an instance of a potentially "scary" use of computer technology facilitated by the US military command. Alexei Yurchak has discussed in depth how the "Imaginary West" was used as a negative point of reference in the USSR juxtaposed with positive images of currents of the Soviet Union. ${ }^{16}$ Information about recent developments in telecommunication technologies by the military-industrial complex in the West, contrasted with peaceful applications in the Soviet Bloc, played a similar role in Polish media discourse.

11 By contrast, in Western media discourse, the hacker peril, popularized by the film War Games (1983) offered not only the vision of American adolescents tinkering with computers, but also of a Soviet intrusion into telecommunications networks. As one The Risks Digest contributor wrote :

If it were in the Soviet Union's vital interest to wreck the operation of the phone system, and they were willing to spend a few billion a year to do so, of course they could do it. ${ }^{17}$ 
12 It is also interesting to consider both sides of the story of computer viruses from the 1980s. The Polish computer magazine IKS (Informatyka Komputery Systemy), published by the military publishing house, quoted an article from Soviet Pravda with a story about a recent visit of American students to one of the Soviets' computer centres. According to this story, one of the students brought some floppy disks infected with viruses, which then spread in the centre. However, the article reassured readers that "Soviet scientists are intensively working on finding a cure for this peculiar electronic illness." ${ }^{18}$ Among computer professionals in the West in late 1980s, Bulgaria's rising software industry became known as a virus factory. Experts from American antivirus companies claimed that in a single year, 1987, Bulgaria released seventy-six viruses, giving it the dubious privilege of being the "world's single largest virus contributor." ${ }^{19}$ Among those viruses was the Dark Avenger, considered the most malicious PC virus at the time. Viruses could thus be viewed as a peril that came from the West to intentionally or unintentionally disrupt Soviet computer networks or as a product of an orchestrated Bulgarian virus-manufacturing program that aimed to disrupt American networks.

Authors of a popular book on media piracy in the 1980s even claimed that : "It is believed that in 1981 Soviet scientists working in Eastern Europe twice managed to break into major western computer networks, and it has probably happened many times before and since." ${ }^{20}$ The testimony of an American computer hobbyist from Oklahoma shows how the attempts of a Polish modem user to establish a connection with American hobbyists was rather unwelcomed by US governmental agencies. In the 1980s, he established a connection with an unnamed Pole through FidoNet, then a highly popular modem data transfer protocol that enabled easy international communication with other computers used as "gateways," which forward messages to other recipients.

I started communicating with the fellow in Poland, regularly helping him getting his FidoNet going [...] I was his gateway out of the Poland [...] I am sitting at home one day and got this knock on the door and it's two guys in the suits and they want to talk to me. They asked me [...] if I ran a lot of equipment that use the modem. And I said "Yes, I do." [...] And they said "We need to speak with you." They wanted the explanation what this was. We went to the backroom I showed them computer equipment [...] Finally they got to the point. "Did you communicate with this individual in Poland ?" "Well, yes I do" [...] "We would like to know why you are sending him encrypted communications to a communist country?" So I showed them the communications I've been doing. At this point it was obviously clicked for them that... I didn't understand any politics involved ... They left with the comment... "You need to understand that people in Poland have to register copy machines so imagine what kind of person you are talking to who owns a computer with a phone line." With that they left. ${ }^{21}$

As I will further show, while in the US, a Polish computer modem user accessing a computer network was considered an intrusion into the "closed world," in Poland at the same time, this kind of activity was rather welcomed as an instance of normalization and "catching up with the West." During my research I was unable to find any source suggesting that any Polish governmental or law enforcement agencies attempted to control or discourage modem users from establishing modem connections across the Iron Curtain. ${ }^{22}$ 


\section{Networks for economic and social management}

15 This section discusses how the discourse of economic progress influenced plans to develop Polish computer networks in the 1970s. While studying the attempts to establish the "automated information system" in the USSR, Gerovich showed how computer professionals and supporters of cybernetics successfully promoted this communications system by providing it with political meanings, thus making it accessible and acceptable to policy makers. ${ }^{23}$ This case shows how technical experts are capable of shaping "scripts" of technology use. Madeleine Akrich in her influential paper on this matter discussed the role of such experts :

Engineers, managers, and designers not only define the characteristics of the emergent artifacts but also define actors with specific tastes, competences, motives, aspirations, political prejudices and the rest. ${ }^{24}$

16 In 1960s Poland, the computer professionals who established the computer manufacturing state enterprise Elwro in Wrocław successfully convinced policy makers that computers were not only capable of solving abstract mathematical problems, but could also be successfully applied in the management of centrally controlled economic and social planning. Beyond this milieu of computer professionals, economists, heavily influenced by cybernetics at that time, also supported the application of computers to enhance socialist economic management. In 1967 Oskar Lange published an influential paper entitled "The Computer and the Market," where he argued that computer systems were capable of successfully controlling the centrally planned economy. ${ }^{25}$

17 To implement such control and management, it was necessary to plan and develop a system of "information transfer" which would connect computers in relevant state institutions. Two resolutions of the Council of Ministers, in 1964 and 1965, acknowledged "research on information transfer and the use of data processing for planning and management" as significant areas for state-supported research and development (R\&D). ${ }^{26}$ In 1966, Nowe Drogi [New Paths], a monthly journal and the official organ of the Polish United Workers' Party (PZPR), which usually published speeches of top-rank party officials, published an article by Eugeniusz Zadrzyński on the role of computers in state socialism. ${ }^{27}$ Zadrzyński was an engineer and party activist who was shortly appointed as the chief of a government department of energetics. In the Nowe Drogi article, he discussed on-going trends in the West: "In the world, electronic calculating machines are applied [...] in all areas where speeding up information circulation enables the improvement of decision-making processes. ${ }^{\prime 28}$ As he further argued, the same means should be implemented to improve decision-making processes in social and economic planning in Poland. At that time in Poland there were no automated information transfer networks. Computer data could only be transferred by the circulation of magnetic tapes or punch-card data. This method of data circulation was used in the ZETO (Zakłady Elektronicznej Techniki Obliczeniowej - Electronic Data Processing Works) computer centres that provided state enterprises and institutions with computer access and calculating power.

The first nationwide computer network dedicated to economic and social planning, to be named MERKURY, was proposed in 1973 during a conference on the development of "Nationwide Data Processing System. ${ }^{\text {“29 }}$ The eighteen-page MERKURY proposal document is a detailed description of the conceptual system of state-socialist, centrally planned 
economies and social planning systems. It explains in detail how several state agencies and enterprises should be engaged in an automatic system of data circulation. One of the interesting features of this plan is a collection of diagrams showing a conceptual model of the MERKURY as a complex network of interdependencies connected with one or two side arrows. These diagrams provide a clearer picture of the whole system and show a graphic model of the power structure as several simultaneous acts of communication. It shows an imaginary process of communication in state socialism, thus revealing how an imagined network articulates discrete connections between relevant state agencies. Such diagrams are not only plans of a computer network, but also diagrams of the basic model of the power relations between the state, the economy and society in the political imaginary of state socialism.

In the MERKURY proposal, state enterprises were ordered to transfer data on actual production output as feedback to relevant ministries and to the Central Statistical office. With the full set of economic data available, they should be able to make decisions on eventual change in the central economic plan and implement these decisions through the same automated system. The basic rule of the system, and the most frequently used term in the document, is "management" ("zarzĄdzanie"). This term at the same time refers to the power configuration in the whole centrally planned, state socialist economy and to the Taylorist principle of scientific management. Every participant of the system was engaged in an automated process of sending reports to other agencies located higher or, rather, more "centrally," in the power structure and stood ready to implement orders sent as automated feedback.

It is important to emphasize the use of term "user" ("użytkownik") in relevant state documents. Here this term always refers to an organizational structure rather than an individual human being. Virtually all documents which discuss computer networks before the mid-1980s consider only organizational structures such as governmental agencies, companies or research institutes as possible "users." At that time, there were no privately owned computers, and in both the capitalist and socialist worlds, all mainframe computers were used only in organizational structures. However, documents such as the MERKURY proposal, written in a specific bureaucratic jargon, also refer to an organizational culture of state socialism, where no single human being, but rather collective institutions had agency and could influence other bureaucratic structures. The socialist culture of collectiveness is embodied by the propaganda image of Politburos collective and unanimous ruling bodies. ${ }^{30}$ MERKURY's primary aim was to provide decision-making bodies with a means of carrying out fully rational, thus more efficient, planning based on scientific methods. In both means and aims, the MERKURY plan was completely consistent with communist ideological principles and merged the language of cybernetics with communist party jargon. The MERKURY plan could be read as an unfulfilled vision of a group of cyberneticists and computer professionals. However, it also provides insight into an attempt to apply technology to achieve a fully efficient system of economic and social planning, one of the foundational elements in the imaginary future of Communism.

21 In 1974 the Council of Ministers approved a resolution in which the development of the System Informatyczny Planowania Centralnego or CENPLAN (a Soviet-style acronym of CENtralne PLANowanie - Central Planning), based of the MERKURY system. was included in a plan of the development of the computer industry. The governmental decision outlined CENPLAN as "a governmental system of automatic data collection, processing, 
and sharing of data which are intended for the needs of central planning of the state's social-economic development." ${ }^{31}$ This system was supposed to use a nationwide, dedicated telecommunications network and, as the document stated: "The Minister of Communications is currently developing a long-standing program of building nationwide data transmission networks. ${ }^{32}$ However, the CENPLAN was plausibly developed only as an administrative system with little or no use of telecommunications technology.

Development plans for several computer and telecommunications systems were included in the central plans for technological development in the years 1986-1990. The official plan for technological development for 1986-1990 acknowledged by the the Council of Ministers included a number of focal points for further technological progress: "The development of new generation supercomputers with the application of artificial intelligence, the development of mass means for data processing technologies, professional and personal computers, modern communication systems." ${ }^{33}$ Such plans were not backed up by any specific measures, and they were extensively criticized by columnists in Komputer magazine), which actively promoted computerization of Poland. For instance, in 1986 a Komputer columnist ridiculed a claim of the Vice Prime Minister in the Polish economic journal Rynki Zagraniczne [Foreign Markets] on the role of Polish participation in COMECON. The Vice Prime Minister claimed that Poland would soon specialize in "the development of superfast computers," "fibre optics communications systems" and a "new generation of telecommunications and television transmission satellite systems." ${ }^{34}$ Komputer columnists argued that neither "superfast computers" nor the "new generation of satellite systems" could be built in Poland since governmental agencies responsible for the support of R\&D in IT technologies, aside from public claims, offered no coherent policy. Nevertheless, we can read such claims as propaganda whose aim was to show that the Polish government was actively carrying out a policy of "catching up with the West" in terms of technological progress.

In the next section, I discuss the very limited development of academic computer networks in the 1980s. However, it is necessary to point out one computer network beyond academia that did exist. In the early 1980s, the Polish national airline LOT joined SITA (Société Internationale de Télécommunications Aéronautiques), an international, modem-network based reservation system. ${ }^{35}$ Poland had a shared computer server in Atlanta to share information with American airlines and travel agents on popular flight routes from Poland to the US. This system was highly welcomed by the editors of Bajtek popular computer magazine as a working international computer network, which shows that, despite the on-going political and economic crisis of the 1980s, Poland was attempting to catch up with the West. ${ }^{36}$ It is worth noting that this system had no dedicated communication infrastructure network, but rather utilized the public telephone network. The poor quality of the telephone infrastructure meant that when a single telephone line near Warsaw failed in 1987, Poles were left unable to book any international plane tickets for a few days. ${ }^{37}$ As we shall see, the poor quality of the telephone infrastructure was also a significant problem for individual Polish modem users.

Another interesting case is the establishment of international telecommunications systems. The Soviet Intersputnik satellite launched in 1974, and the main Polish satellite telecommunications centre was opened in Psary in central Poland the same year. Intersputnik was used for the retransmission of television broadcasts, mostly from the Soviet Bloc states. In a press article, the former Director of the Psary Centre, Wiesław 
Dzierżak, explained that despite extensive costs, Poland also had to join the maritime satellite telecommunications system INMARSAT in 1987 because, beginning in 1988, the British Lloyd's Register refused to register any civilian vessels without this system. ${ }^{38}$ Polish networking with both the SITA and the INMARSAT systems signals how a state-socialist country actively chose to join international telecommunications networks in order to continue commercial operations in a global marketplace.

\section{Contested visions of international scientific networks}

All of the imagined, proposed and planned networks discussed in previous section were based on acts of communication between institutional actors such as administrative units and state owned enterprises. Even though few of these networks came to fruition, at the same time the concept of a computer network became recognized as a viable system of communication by the academic community. Here we can see how plans of computer networks articulated the structure of pre-existing scientific community as a network of research centres and individual scientists. ${ }^{39}$ At the same time access to computer networks provided scientists with new opportunities to foster academic collaboration. In his study on the post-war internationalization of scientific life in Western Europe, John Krige discussed the rise of academic exchange between the US and Europe and outlines an on-going process of "scientific internationalism." "Internationalism' was intrinsic to the scientific ethos, and international scientific exchange and collaboration was a well-established mode of communication between scientists in different countries." Krige discussed state-sponsored research exchange systems which, much like to the Marshall Plan, aimed to build closer ties between the US and European states. A similar ethos of "internationalism" was also embedded in the discourse supporting the development of international academic contacts within the Soviet Bloc. ${ }^{41}$

In Poland the first actual computer network that linked geographically dispersed centres was CYFRONET used by the Instytut Badań JĄdrowych (IBJ, Institute for Nuclear Research) in Świerk near Warsaw. This network, opened in June 1973, was based on a central computer Cyber 72 bought from the Control Data Corporation (CDC). The computer itself was located in a research centre that operated the nuclear reactor in Świerk. CYFRONET used the public telephone network, and linked IBJ with ten research centres in Warsaw with modems. The main purposes of CYFRONET were "the remote control of large and complex data processing tasks" and "the distribution of experimental data from the scientific nuclear reactor in Świerk" to research institutes, which would process them. ${ }^{42}$ This system was supposed to bring about the internationalization of research among nuclear physicists. "Using large software and data banks through internal exchange and international cooperation" was declared as a future application of CYFRONET. ${ }^{43}$ Zurich, the Institute for Energy Technology in Kjeller (Norway), the Boris Kidrič Institute of Chemistry in Ljubljana and the Saclay Nuclear Research Centre (France). ${ }^{44}$ However, no available records indicate what kind of cooperation actually took place. Frank Dittman, in his detailed study of the development of international computer networks in the Soviet Bloc, pointed out that the International Institute for Applied Systems Analysis (IIASA) in Vienna also played a significant role as an intermediary that helped to build the infrastructure for international data transmission. But, similarly, I was unable to find any relevant records on Polish participation in this network. ${ }^{45}$ 

and data exchange was feasible at all. The development of advanced technologies related to the peaceful application of nuclear energy was extensively used in Soviet Bloc propaganda where it was contrasted with the malevolent application of nuclear energy by, in the common ideological label for Western capitalist countries, "imperialist warmongers. ${ }^{" 46}$ Informatyka, a Polish journal for computer professionals from 1977 clearly shows how the concept of computer networks was articulated as a development consistent with communist ideological principles.

The fostering of cooperation between remote research centres will be possible with information transmission [...] Computer networks would enable people from different countries to learn about each other, to find a common language, and to share data and experiences. We hope that networks will become a positive factor for science and for humankind. ${ }^{47}$

In this quotation we can see how Polish computer scientists used the highly standardized language of communist propaganda in an attempt to define computer network technology as acceptable and desirable to policymakers.

More academic computer networks were developed in the 1980s with the flagship state program named Mį̨dzyuczelniana Sieć Komputerowa (Inter-University Computer Network). ${ }^{48}$ ) in Moscow. This connection was supposed to enable researchers from both countries to access databases from the fields of social, economic and natural sciences. ${ }^{49} \mathrm{In}$ 1987, the establishment of a Council for Mutual Economic Assistance (CMEA)-wide scientific computer network was discussed. but it is unclear if any plans were implemented." ${ }^{50}$

In the mid-1980s US, the BITNET network system (est. in 1981) became widespread among the natural sciences academic community as a means of keeping daily contact and circulating research data among members of geographically dispersed research teams. ${ }^{51}$ At the same time, researchers from several Western European countries established international EARN (European Academic and Research Network), which aimed to foster academic collaboration at the international level. ${ }^{52}$ Polish scientists who managed to get academic fellowships in the West learned how to use this system. Polish physicist Jacek Gajewski recalled :

As (mostly) high energy physicists, who usually work in large international collaborations, we used BITNET extensively during our stays in other countries, and felt very handicapped without it at home..$^{53}$

Another scientist, Tadeusz WEggrzynowski, with a background in electronic engineering remembered how he attempted to keep up his BITNET contacts upon returning to Poland :

My first contact with BITNET was in Canada, in 1988. [...] When I came back to Poland for a couple of months, I installed several connections from PC's to our mainframe at the University of Warsaw. At this time, I was only dreaming about electronic mail from Poland to Canada and the world [...] The fastest way of sending letters to Canada was by the help of strangers flying to Toronto. It worked, but it was difficult and it took a lot of time. This way many Polish scientists, cooperating with their partners in other countries, exchanged mail. ${ }^{54}$

31 Howard Davies and Beatrice Bressan, while discussing the rise of international computer networks in Europe of the 1980s, claim that the issue of linking Poland and Hungary to the EARN was discussed in $1985 .{ }^{55}$ At that time, the main obstacle was the CoCom 
(Coordinating Committee for Multilateral Export Controls) controlled mostly by US governmental agencies, which routinely voted against internationalization attempts. ${ }^{56}$ the US, established a telephone modem-based Bulletin Board System (BBS) forum named "EARN-Poland Link Discussion" and later a second forum "BITNET to Poland" (1988). ${ }^{57}$ In an article in influential Polityka weekly magazine from 1994 this dispersed scientific community of Polish scholars linked with computer networks was referred as an "electronic diaspora." 58 Zieliński and his colleagues from the academic community started a public campaign to win US Department of Commerce (DoC) permission to access international academic networks. As Zieliński claimed, export restrictions made it impossible to join both BITNET and EARN. The campaign petitioning the DoC was supported by prominent figures such as Ira Fuchs, the founder of BITNET, and Stefan Amsterdamski, a renowned Polish historian of science who also had personal contacts abroad. While trying to gain support and submitting petitions to the DoC, Polish scientists managed to cope with existing constraints by using a telephone modem-based FidoNet system to communicate with other members of their research groups abroad. Zieliński remembered :

The electronic contacts with Poland were soon becoming more frequent. Although there was no EARN node in Poland yet, a number of researchers participating in joint programs with universities in Germany, Denmark and Switzerland obtained accounts on the university computers, which they could access also from Poland. ${ }^{59}$

In the end, Polish universities were able to join EARN only in 1990, when the Cocom lifted the ban on computer and telecommunication technologies exports to Eastern Europe. ${ }^{60}$ The official announcement of Poland and other Eastern European countries' access to EARN took place on April 10, 1990. The first EARN Polish node named PLEARN4 was opened on July 7 at the University of Warsaw. Smereczyński remembered :

This was the day [April 10, 1990] when everybody's efforts to bring The Network to Poland had been crowned. The solemn announcement of the formal EARN vote result was heartrending, especially when heard from the EARN president, Mr. Frode Greisen himself at the Senate Hall of Warsaw University. It admitted Poland, Hungary, Czechoslovakia, Bulgaria and the Soviet Union to EARN. A lucky day for the Polish academic community. In my opinion, that extraordinary moment was more important for Europe than the destruction of the Berlin Wall, because, if the Berlin Wall was a symbol and nothing else, then the first EARN link with Poland could be considered the real creation of the ties bringing the former Eastern Block together with Europe. And this positive movement started again from Poland. ${ }^{61}$

Clearly, the establishment of a network system dedicated to academic data exchange had a symbolic value for the academic community. Smereczyński's testimony touches upon a significant question about different moments in the period of transition that could be considered relevant to the end of the Cold War. Here we can see that joining the telecommunications system could be identified as a moment of a significant transition, a literal joining of two previously closed worlds.

Attempts to link Poland to EARN, which according to Badenoch and Fickers can be definitely considered a "contested process" in the emergence of international telecommunications infrastructure, show the clash of two visions of computer networks. First was the ethos of academic "internationalism" in which international contacts among academics can only foster the development of science viewed as a common good. The second vision, as US governmental policy and the CoCom show, was embedded in the 
notion of a "closed world" that should be not penetrable by anyone from the other side of the Iron Curtain.

\section{Computer modems and catching up with the world} computer at home enabled private users to join the "electronic community" of computer
hobbyists. In 1980s Poland, computer hobbyists gathered in state-sponsored computer clubs. Two Polish magazines, Bajtek (1985-1996) and Komputer (1986-1990), played an influential role as a source of technical information and a cultural intermediary for such circles. ${ }^{62}$ Both periodicals regularly published articles with practical information about modem use and encouraged readers to use modems to contact with other modem users in Poland and abroad. Moreover, their editors appealed to governmental agencies for official acknowledgement of modem use and support since, as they argued, joining international electronic communities with telecommunication technologies is one of the indicators of belonging to the developed world. The editors of both magazines as well as club activists established extensive international contacts with their counterparts both in the Soviet Bloc and Western Europe using snail mail as well as modems. System as the basic means of communication for sending information and for the distribution of software. The high price of long-distance calls and modem connections stimulated the development of software that offered late-night dialling to other bulletin boards for the exchange of messages. In these systems, BBS nodes were used as gateways for the transmission of received messages addressed to other computers. The most popular such protocol was FidoNet which gained popularity both in the US and Western Europe. ${ }^{63}$ In Europe the most prominent computer club was the Dutch Hobby Computer Club (HCC), which boasted an extensive network of foreign contacts. One of the club activists, who was also the HCC FidoNet sysop (system operator), was a Polish émigré named Maciej Kollo who worked in the Dutch IT industry. ${ }^{64}$ In 1986, Kollo established contacts with the editors of Komputer. During a visit of the magazine's editors to a computer fair held by the HCC in Utrecht, the HCC officially provided Poles access to FidoNet's global networks through the HCC gateway.

Komputer magazine extensively discussed the potential advantages of FidoNet. Finally on July 29, 1987 the first Polish FidoNet node was opened on a computer in Komputer's editorial office. ${ }^{65}$ Between 1987 and 1989, Komputer regularly published calling numbers and brief information on other Polish network nodes as well as technical hints and information on modem registration. The number of FidoNet users in Poland could be estimated at a few dozen. In April 1989, Komputer claimed that the magazine's FidoNet node has 150 registered users who logged on frequently. ${ }^{66}$ However, other information from members of the FidoNet community claimed that in 1989 there were about a dozen of private users who established their FidoNet nodes. ${ }^{67}$ It is plausible that virtually every member of the FidoNet community was a computer professional working at a university or in the electronics industry.

39 It is also difficult to describe the actual uses of modem-based computer networks at that time. The title of an article on FidoNet in Informatyka journal, "FidoNet - an international amateur computer network" shows the symbolic meaning of this system as one that provided Polish computer amateurs with the means to connect to a broader community. ${ }^{68}$

Cahiers du monde russe, $56 / 2-3$ | 2015 
It also indicates that, unlike exclusive academic networks such as EARN discussed above, FidoNet was open to a broader group of computer aficionados. It is difficult to estimate if this network was used in Poland to send any programs or only sporadic messages. However, in the 1980s, FidoNet was considered a state of the art and elitist "electronic community" in circles of computer users, and accessing this system had significant symbolic value because it provided a symbolic membership in this worldwide community.

To better understand the context of the rise of FidoNet use, it is important to ask about the possibilities of using of a modem in state socialist Poland. Discussions about the dissemination of privately-owned computer modems and the legalization of modem show that these currents were generally accepted, or even welcomed, by the Ministry of Communications responsible for telephone infrastructure. Modem-based computer networks, which enabled international connections, used the public telephone system not specifically dedicated to modem use. ${ }^{70}$ The only technical requirement for modem use was the necessity of access to a telephone network with an automatic switching system. It was impossible to use a computer modem with manual switching boards, which were still used in Polish telecommunications in the mid-1980s. On the one hand, the telephone modem offered computer network access to anyone who owned a landline could access to an automatic switching board. On the other hand, it caused several problems since the telephone companies and state agencies that controlled public communications (such as the Federal Communications Commission in the US) were rather reluctant to adopt or promote modem use.

41 In Poland, an international semi-automatic switching system was introduced in the late 1960s. In propaganda newsreels from 1968 and 1972, the introduction of this system was shown as a symbol of technological modernity and opening up to the world beyond the Iron Curtain. In both newsreels - "Colleagues from the telephone exchange" and "Conversations with the world"- female operators responsible for switching were shown at work while making arrangements with callers in English, German, and Italian. They were also shown chitchatting with their counterparts in other countries. This kind of activity was highly unwelcomed in Western telephone companies. However, in communist propaganda newsreels, the meaning of the scenes was different. This newsreel refers to a broader theme of Polish propaganda of the 1970s, a time of relative opening to the West. Female telephone operators chitchatting in fluent English or Spanish were shown as modern Poles successfully catching up with the West. ${ }^{71}$ It is unclear when exactly Poland introduced fully automated switching boards for international calls, but in the mid-1980s such connections were available for calls to all socialist countries, except Romania, and most of Western Europe, including the Netherlands. ${ }^{72}$

Jan Stożek, one of the pioneers of FidoNet in Poland, claimed that he became interested in modem use in the mid-1980s while visiting the Netherlands and observing how HCC members were using modems to communicate with other computer clubs around the world. ${ }^{73} \mathrm{He}$ recalled that at first he and his colleagues doubted if it would be feasible to use modems in Poland at all. It is unclear if he was referring to technical or political obstructions. One of the first Komputer articles on modem use claimed that aside from the prohibitive price (about $\$ 100$ for an imported modem), it was simply illegal to use a modem according to the current law that forbade sending "encrypted messages" by phone. ${ }^{74}$ This article referred to regulations from before June 1986, when a resolution of the Ministry of Communications allowed "teleinformatic connections" (połĄczenia 
teleinformatyczne). ${ }^{75}$ As one Ministry of Communications official claimed in 1986, two months before the introduction of the resolution, the Ministry already allowed modem use for registered users. There were, he maintained, a few dozen registered users, and "some of them even managed to establish highly remote connections, even with the US." 76

Much like the propaganda newsreels mentioned above, such claims had a particular propaganda value. In the 1960 s and 1970s, both the introduction of semi-automated switching boards and the fluency of female Polish operators in foreign languages could be shown as indicators of successes in the recent policy towards opening to the West. Similarly, claims about possible modem connections with the US were proof that despite the political and economic crises of the 1980s and Western economic restrictions, Poland was still moving forward in terms of technological progress, and Polish computer users had access to a state of the art telecommunications system.

According to the new regulation, modem users had to register with the Ministry, provide a homologation certificate for any privately-owned modem, pay a monthly fee, and deposit a floppy disk with their data transfer protocol. ${ }^{77}$ The Ministry of Communication adopted the international modem homologation standard known as the CCITT (Comité Consultatif International Téléphonique et Télégraphique) V.21. ${ }^{78}$ Modems compliant with this norm were approved without the need for highly expensive homologation. A restrictive approach to homologation and technical norms was fully understandable at that time since several computer peripherals could cause significant interference with television and radio signals. One computer journalist wrote that bureaucratic problems with modem use lasted in Poland after 1989. As he claimed, during his visits in the Ministry of Communications he was told the basic reason why the Ministry intended to raise the charge for modem use. According to the unnamed Ministry official, the charge for using a modem should be higher than that for a telephone call since, as he claimed, modems overload telephone networks, cause faster wear, and require more electrical power. ${ }^{79}$ Given the lack of any particular sources on possible constraints on modem use of a political nature in the 1980s, the high rates for modem registration and the general reluctance of Ministry office clerks mentioned in Bajtek and Komputer could be simply explained by the nature of state socialist bureaucracy, which did not suddenly disappear after year 1989.

Aside from the prohibitive cost of a modem itself, there were two other constraints on modem use in state socialist Poland. The telephone itself was at that time still a rarity in Polish households. Another problem was the poor quality of the telephone networks. ${ }^{80} \mathrm{As}$ Prof. Władysław Majewski, the Minister of Communications, admitted in an interview for Komputer, modem users were welcomed by his institution; however, he also openly admitted that it was virtually impossible to establish even a domestic modem connection during working hours because of the overload and poor quality of the telephone network.

The case of the modem shows that in order to understand the domestication of communications systems, we need to consider the often mundane materiality of communications technologies. ${ }^{82}$ One can ask why the Ministry of Communications introduced the legal framework and procedures for private modem use since, as we have seen, there were no more than a few dozen potential users. The Minister claimed that his decision to provide resources for the improvement of modem communications and the development of an administrative unit responsible for modem use was highly criticized in 
the upper ranks of communist party. ${ }^{83}$ As he explained, he was criticized because he diverted resources from attempts to increase the number of household telephones. At that time, less than one half of Polish households had a telephone, and the number of telephones was one tangible indicator of a country's modernity. In 1986, the Polish government started a massive program of the "electronization of the national economy" whose aim was to stimulate R\&D and manufacturing in electronics and the development of telecommunications networks as means of modernizing and levelling the "technology gap" between Poland and the West. ${ }^{84}$ We can assume that the resources were diverted to the introduction of modem use, since modem-based computer networks were a symbol of technological modernity with propaganda value, showing that socialist Poland was successfully levelling the "technology gap" between the highly developed West and the Soviet Bloc.

\section{Conclusion}

This article has shown how imagined, proposed and planned computer networks in Poland in the 1970s and 1980s were embedded in the discourse on economic, social and scientific progress. As Badenoch and Fickers argue, instead of trying to grasp the social change caused by the development of communications infrastructure, it is more useful to explore the "contested process" of making a network. Studying these processes also sheds light on relatively unexplored aspects of the cultural and media history of the Soviet Bloc. The plans to build computer networks in the late 1960s were clearly influenced by the enthusiasm for cybernetics. However, at the same time, the acceptance of these plans by decision makers shows that computer networks had been successfully presented to them as a means of economic and social progress that fit in with communist ideological principles. Also, attempts to use computer networks for the "internationalization" of science definitely fit into broader patterns of change in the Soviet Bloc, showing that state socialist countries were relatively eager to open up to the world by enabling particular forms of the flow of people, commodities, and information across the Iron Curtain.

Traditionally studies of media communications in the Soviet Bloc emphasize the role of state-owned media as a means for the distribution of propaganda content, or alternative media systems as an attempt to challenge state control. This study offers a different perspective. Instead of showing how computer and modem users simply challenged the state monopoly in telecommunications, I have shown how eagerly bureaucrats acknowledged the use of privately-owned modems, since they were already part of the public discourse of techno-scientific progress. This case also shows how the US state agencies played a role in hindering the development of international computer networks. Thus, the same technological system could be considered by different historical actors as a means of social and scientific progress or as a national security concern. Further studies of such "contested processes" in the emergence of media and telecommunications systems in the Soviet Bloc could help us to better understand how the Cold War was a time when political and military confrontations overlapped with public enthusiasm towards visions of technological modernity. 


\section{NOTES}

1. I would like to express my gratitude to Kristin Roth-Ey, Larissa Zakharova and two anonymous reviewers for their valuable comments that helped me to improve this article. Research for this article was supported with National Science Centre grant 2013/08/S/HS2/00267.

2. Paul Edwards, The closed world : computers and the politics of discourse in Cold War America (Cambridge : MIT Press, 1996).

3. For a comprehensive history of technological communication systems, see Laszlo Solymar, Getting the Message : A History of Communications (Oxford - New York : Oxford University Press, 1999). For a discussion of the political economy of contemporary communications systems, see : Vincent Mosco, The Political Economy of Communication, 2nd ed. (Los Angeles et al. : SAGE, 2009). For historical analyses of the social impact of ICT, see Eugene Loos, Leslie Haddon, and Enid Mante-Meijer, The Social Dynamics of Information and Communication Technology (Aldershot - Burlington: ASHGATE, 2008) ; Robert Kraut, Malcolm Brynin and Sara Kiesler, eds., Computers, Phones, and the Internet: Domesticating Information Technology (New York Oxford: Oxford University Press, 2006); Brian Winston, Media Technology and Society: A History : From the Telegraph to the Internet (London - New York : Routledge, 1998).

4. Edwards, The closed world, 1-41.

5. Alexander Badenoch and Andreas Fickers, "Introduction. Europe Materializing? Toward a Transnational History of European Infrastructures," in Alexander Badenoch and Andreas Fickers, eds., Materializing Europe : Transnational Infrastructures and the Project of Europe (Houndmills - New York : Palgrave Macmillan, 2010), 1-23, here 4.

6. Janet Abbate, Inventing the Internet (Cambridge - London: MIT Press, 1999) ; Janet Abbate, "Cold war and white heat : the origins and meanings of packet switching," in Donald MacKenzie and Judy Wajcman, eds., The social shaping of technology (Buckingham : Open University Press, 1999), 351-371.

7. Vincent Mosco, The Digital Sublime : Myth, Power, and Cyberspace (Cambridge - London : MIT Press, 2004).

8. Slava Gerovich, From Newspeak to Cyberspeak : A History of Soviet Cybernetics (Cambridge London : MIT Press) ; see also : Benjamin Peters, "Normalizing Soviet Cybernetics," Information \& Culture. 47, 2 (2012) : 145-175.

9. Edwards, The closed world, 1-41.

10. Charles P. Bourne and Trudi Hahn, A History of Online Information Services, 1963-1976 (Cambridge - London : MIT Press, 2003).

11. Gerovich, From Newspeak to Cyberspeak; Eden Medina, Cybernetic Revolutionaries: Technology and Politics in Allende's Chile (Cambridge - London : MIT Press, 2013).

12. For a discussion of the rise of interest in computer technologies among the party elite in the USSR, see : Erik P. Hoffman, "Technology, Values, and Political Power in the Soviet Union : Do Computers Matter?," in Frederic J. Fleron, ed., Technology and Communist Culture: The Socio-Cultural Impact of Technology under Socialism (London - New York : Praeger Publishers, 1972), 397-436.

13. See : Richard Barbrook, Imaginary Futures : From Thinking Machines to the Global Village (London - Ann Arbor : Pluto Press, 2007).

14. Thierry Breton and Denis Beneich, Softwar (New York : Henry Holt \& Co., 1986). Quote after : The Risks Digest, 2, 42 (14 Apr. 1986), http://catless.ncl.ac.uk/Risks/2.42.html\#subj3.1. 
15. Zbigniew Cywiński, "Co nas interesuje ? [What interests us ?]," IKS. Informatyka Komputery Systemy, (Jul.-Aug. 1988) : 18.

16. Alexei Yurchak, Everything Was Forever, Until It Was No More : The Last Soviet Generation (Princeton - Oxford : Princeton University Press, 2005), chapter 6, Kindle edition.

17. Richard A. Cowan, “Cohen's AT\&T SDI Software Analogy," The Risks Digest, 1, 32 (23 Dec. 1985), http://catless.ncl.ac.uk/Risks/1.32.html\#subj2.1

18. "Koniec 'dżumy' [The end of the 'plauge']," IKS. Informatyka Komputery Systemy, (Feb. 1989) : 28. Summary of an article "The end of the "plague"' [Original title in Russian not included] from Pravda, 12 Nov. 1988.

19. Stefan Helmreich, "Flexible Infections: Computer Viruses, Human Bodies, Nation-States, Evolutionary Capitalism," Science, Technology, \& Human Values, 25, 4 (Autumn, 2000) : 472-491, here 483.

20. John Chesterman and Andy Lipman, The Electronic Pirates: DIY Crime of the Century (London : Routledge, 1988), 81.

21. "The Poland Story," Interview with Mark Grennan (Oklahoma City) conducted by Jason Scott, Jan. 29, 2004 in Jason Scott Sadofsky, BBS: The Documentary (DVD) (Boston: Bovine Ignition Systems, 2005), included on DVD as a bonus feature, https://www.youtube.com/watch? $\mathrm{v}=$ UbtD1z7grzI. There is no hard evidence to verify such testimony, which could be considered as a part of hacker mythology. However, this sort of warning visit from "G-men" is consistent with information about the FBI interest in American computer modem users frequently discussed in contemporary hacker periodicals such as " 2600 The Hacker Quarterly" and "cDc [Cult of the Dead Cow] Communications," http://w3.cultdeadcow.com/cms/texXxt.html. See also: Douglas Thomas, Hacker culture (Minneapolis : University of Minnesota Press, 2003).

22. I asked two researchers from the Institute for National Remembrance (IPN), familiar with techniques of telephone tapping and eavesdropping by the secret police and the ELINT (electronic intelligence), if modem communications was subject to eavesdropping in state socialist Poland. Both claimed that they never found any record that would suggest the Polish secret service ever eavesdropped on private modem users in Poland who were engaged in establishing international contacts.

23. Slava Gerovich, "InterNyet: why the Soviet Union did not build a nationwide computer network," History and Technology, 24, 4, (Dec. 2008) : 335-350.

24. Madeleine Akrich, "The De-Scription of Technical Objects," in Wiebe E. Bijker and John Law, eds., Shaping Technology/Building Society: Studies in Sociotechnical Change (Cambridge London : MIT Press, 1992), 205-224, here 208.

25. Oskar Lange, "The Computer and the Market," in Hilliard Feinstein, ed., Socialism, Capitalism and Economic Growth: Essays Presented to Maurice Dobb (New York: Cambridge University Press, 1967), 158-161. Article available: http://econc10.bu.edu/economic_systems/Theory/ NonMarx_Socialism/Soc_Contraversy/lange_computer_and_the_market.htm.

26. “Uchwała RM nr 18/64 z dnia 22 stycznia 1964 r. w sprawie rozwoju elektronicznej techniki obliczeniowej [Resolution of the Council of Ministers No 16/64 from 22 Jan. 1964 on the development of the electronic technology of calculating]," PTI (Polish Information Processing Society) KLIO online archive, http://klio.pti.net.pl/ (website temporarily offline, all quoted documents from PTI KLIO available in author's collection). "Uchwała RM nr 388/66 z dnia 13 grudnia $1965 \mathrm{r}$. w sprawie stosowania maszyn matematycznych i analitycznych w gospodarce narodowej w latach 1965-1970 [Resolution of the Council of Ministers No. 388/66 from 13 Dec. 1966 on the application of mathematical and analitical machines in the national economy for years 1965-1970]," 1, HINT. Polska klasyka naukowa i techniczna w sieci [HINT: Polish technological and scientific classics] http://hint.org.pl/res/inf/uchwala_388-1966.pdf.

27. The second half of the 1960s was also a heyday of cybernetics in the Soviet Union, see: Gerovich, From Newspeak to Cyberspeak, p. 253-304. 
28. Eugeniusz Zadrzyński, "Elektroniczne maszyny cyfrowe - niezbĘdne narzĘdzie zarzĄdzania [Electronic digital devices - a necessary means of managment]," Nowe Drogi, (March 1966) : 39-50, here 44.

29. Teresa Iciek and Romuald Rataj, "Koncepcja budowy systemu sterowania rynkiem MERKURY [The concept of building of the market control system - MERKURY]," in Krajowy System Informatyczny na tle zmian w systemie zarzĄdzania [Nation-wide Data Processing System in the context of the changes in the system of management], conference proceedings (Poznan : Towarzystwo Naukowe Organizacji i Kierownictwa, 1973), http://klio.pti.net.pl/., 31-48.

30. For a discussion of organizational structures in a socialist state, see : Peter W. Sperlich The History and Institutional Structure of the Marxist-Leninist Government of East Germany and Some Perspectives on Life in a Socialist System (Westport : Praeger, 2006).

31. “Decyzja nr 3/74 Prezydium RzĄdu z dnia 11 stycznia 1974 r w sprawie zastosowań informatyki oraz rozwoju krajowego przemysłu informatycznego w latach 1974-1980 [The resolution No 3/74 by the Presidium of the Council of Ministers from 11 Jan. 1974 on the application of informatics and the development of national computer industry in years 1974-1980]," 2, http://klio.pti.net.pl/.

32. Ibid., 7.

33. "Program rozwoju nauki i techniki na lata 1986-1990," Komitet do Spraw Nauki i PostĘpu Technicznego przy

Urzędzie Rady Ministrów, Warszawa 1986 [„Program for the development of science and technology for years 1986-1990", Committee for Science and Technological Progress by the Office of the Council of Ministers], Archiwum Akt Nowych [Central Archives of Modern Records] (AAN), UrzĄd Rady Ministrów [Office of the Council of Ministers], 290, sign. 1.5/16, 22.

34. Komputer, July $1986: 4$.

35. For an overview of SITA history, see its website, http://www.sita.aero/about-sita/what-wedo/sita-history.

36. Grzegorz Onicimowski, "Do Rzeszowa przez AtlantĘ [To Rzeszów via Atlanta]," Bajtek, March-April 1986: 4. Klaudiusz Dybowski, "Komputery na OkĘciu [Computers at the OkĘcie airport]," Bajtek, Nov. $1986: 4$.

37. Komputer, July $1987: 10$.

38. Wiesław Dzierżak, "Blisko świata [Close to the world]," Przekrój, (23 July 1995) : 54, http:// mbc.malopolska.pl/dlibra/doccontent?id=61159.

39. For the appropriation of computer networks into work routines within academia, see : John P. Walsh and Todd Bayma, "Computer Networks and Scientific Work," Social Studies of Science, 26, 3 (Aug., 1996): 661-703. The general history of technology in international scientific cooperation is discussed in : Howard Davies and Beatrice Bressan, eds., A History of International Research Networking: The People who Made it Happen (Weinheim : Wiley-Blackwell, 2010).

40. John Krige, American Hegemony and the Postwar Reconstruction of Science in Europe (Cambridge - London : MIT Press, 2006), 10.

41. John Connelly discusses how the rise of international academic contacts in the Soviet Bloc during the Stalinism was as a part of the policy of Sovietization of academic institutions, see : John Connelly, Captive University: The Sovietization of East German, Czech, and Polish Higher Education, 1945-1956 (Chapel Hill - London: University of North Carolina Press, 2000). For a discussion of the social impact of several forms of "internationalization" within the Soviet Bloc after the Stalinist period, see: Włodzimierz Borodziej, Joachim von Puttkamer and Jerzy Kochanowski, eds., "Schleichwege": Inoffizielle Begegnungen sozialistischer Staatsbürger zwischen 1956 und 1989 (Jena : Böhlau, 2010).

42. Roman Żelazny, "Cyfronet w Instytucie Badań JĄdrowych w Świerku [Cyfronet at the Institute for Nuclear Research in Świerk]," Informatyka, 10 (1973) : 6-9. CYFRONET was a Soviet-style acronym that used the Polish word "cyfrowy - "digital" - as a prefix. 
43. Żelazny, “Cyfronet w Instytucie Badań...” : 7.

44. Ibid.

45. Frank Dittmann, Technik versus Konflikt. Wie Datennetze den Eisernen Vorhang durchdrangen." Osteuropa, 59, 10 (2009) : 101-119, http://www.zeithistorische-forschungen.de/ Portals/_zf/documents/pdf/2012-2/Dittmann_2009.pdf.

46. See: Paul R. Josephson, Red Atom: Russia's Nuclear Power Program From Stalin To Today (Pittsburgh : University of Pittsburgh Press, 2005) ; Patryk Wasiak, "'Information, space and atom.' Socialist technological utopia in the post-Stalinist period," (conference paper) Post-Stalinism as an Epoch : Towards a Comparative Societal History of European Communism between 1956 and 1980, Zentrum für Zeithistorische Forschung Potsdam, April 2, 2011.

47. Robert Mahl, "Sieci komputerowe [Computer networks]," Informatyka, (May 1977) : 4-6, here 6.

48. Eugieniusz Bilski, Zbigniew Fryżlewicz, Zbigniew Huzar and Andrzej Kaliś, "Rozległe sieci komputerowe [Wide area computer networks]," Informatyka, (Sept. 1985) : 4-10.

49. Komputer, Aug. $1986: 28$.

50. "Nine CMEA countries are planning to introduce a common information exchange system using advanced technology, and its aim is to accelerate scientific and technological progress." Radio Free Europe/Radio Liberty Research Institute (RFE/RL Research Institute), "CMEA Scientists Linked by Computers for the First Time," 7 Aug. 1987, Open Society Archives, HU OSA 300-8-3, 1, http://www.osaarchivum.org/.

51. David Alan Grier and Mary Campbell, “A social history of Bitnet and Listserv, 1985-1991," IEEE Annals of the History of Computing, 22, 2 (Aug. 2010) : 32-41.

52. Davies and Bressan, A History of International Research Networking, 180.

53. Jacek Gajewski, "Polish BITNET : How It All Started," Pigułki, 6, (5 June 1991), http:// ftp.icm.edu.pl/packages/pigulki/pigulki6.pub.

54. Tadeusz WĘgrzynowski, "Bitnet In Poland - The Beginnings," Pigułki, 5, (15 April, 1991), http://ftp.icm.edu.pl/packages/pigulki/pigulki5.pub.

55. Davies and Bressan, A History of International Research Networking, 19.

56. For an outline of the CoCom policy, see : Frank Cain, "Computers and the Cold War : United States Restrictions on the Export of Computers to the Soviet Union and Communist China," Journal of Contemporary History, 40, 1 (Jan., 2005) : 131-147.

57. For Zieliński's testimony, see: Marek Zieliński, “Widziane z Ameryki [As seen from America]," Poglądy 18, (2011) : 28-33, here 29-30, http://www.zevax.com/poglady/; I would like to express my gratitute to Marek Zieliński for providing me with a lot of useful information and sending a copy of Pigułki magazine.

58. Dariusz Milewski, "Diaspora elektroniczna [Electronic diaspora]," Polityka, (19 Nov. 1994) : 18.

59. Marek Zieliński, "How BITNET Came to Poland," Pigułki, 3, 8 (Oct 8, 1990), http:// ftp.icm.edu.pl/packages/pigulki/pigulki3.pub

60. Joseph Palca, "BITNET Headed for New Frontiers," Science, 2 Feb. $1990: 520$; For the original Ira Fuchs' memorandum and fragments of Fuchs' correspondence with the US DoC, see : "Link to Eastern Europe and PRC," 23 Jan. 1990, http://www.ccwhois.org/ccwhois/cctld/earn.exec22.txt.

61. Andrzej Smereczyński, "One Year of EARN Networking in Poland," Pigułki, 6, 5 (June 1991), http://ftp.icm.edu.pl/packages/pigulki/pigulki6.pub.

62. For the general discussion on Polish computer users from that time, see: Patryk Wasiak, "Playing and copying: social practices of home computer users in Poland during the 1980s," in Gerard Alberts and Ruth Oldenziel, eds., Hacking Europe: From Computer Cultures to Demoscenes (London : Springer, 2014), 129-150.

63. For the history of FidoNet, see : http://www.fidonet.org/. See also the "FidoNet" episode in Scott Sadofsky, BBS : The Documentary, https://www.youtube.com/watch ?v =QlXNXdf6Xh0. 
64. Anonymous, „Pejzaż z wiatrakami [A landscape with windmills],” Komputer, Jan. 1987 : 3, 12 ; Tomasz Zieliński, “Zobaczyć Holandię i... [To see the Netherlands and...]," Komputer, Feb. 1987 : 23-25.

65. Tadeusz Wilczek and Tomasz Zieliński, "FIDO - pierwsze próby [FIDO - the first attempts]," Komputer, Oct. $1987: 12$.

66. Anonymous, "Fido," Komputer, April 1989 : 17.

67. POLAND - ELECTRONIC CONTACTS, Pigułki 5, (15 April, 1991) http://ftp.icm.edu.pl/packages/ pigulki/pigulki5.pub.L. This list also includes „Kremlin FIDO BBS” located in Moscow. This node was run by Tadeusz Radiusz, a Russian of Polish origin. It is unclear how it was possible to establish a modem connection with the Soviet Union at that time.

68. Jan Stożek, „FidoNet. - Międzynarodowa amatorska sieć komputerowa [FidoNet - The international amateur computer network]," Informatyka, (July 1990) : 22-23.

69. For the discussion on the "electronic communities" in the 1980s, see : Bruce Sterling, The Hacker Crackdown : Law and Disorder on the Electronic Frontier (New York: Bantam Books, 1992), http://www.mit.edu/hacker/hacker.html.

70. For a history of telephone networks, see: David Mercer, The Telephone: The Life of a Technology (Westport - London : Greenwood Press. 2006).

71. "Koleżanki z centrali [Colleagues from the telephone exchange ]," Polska Kronika Filmowa (PKF), 65/51A, 1965, http://www.kronikarp.pl/szukaj,30668,strona-3; "Rozmowy ze światem [Conversations with the world]," PKF 72/02B, 1972, http://www.kronikarp.pl/szukaj,53677, strona-2.

72. "Komputerowo - przez telefon [Computer calls throught a telephone]," Głos Wybrzeża, 7 Sep., 1988. Press clipping from the Herder Institut library, Marburg, sign P 608; Jerzy Gospodarek, "Rozmowy zagraniczne [Abroad calls]," Veto, 12 Feb. $1989: 6$. This system was not introduced for calls from Poland to the US. For this reason, Grennan (fn. 20), as he claimed, had to provide a gateway for an unnamed Pole who could send his e-mails through FidoNet in the Netherlands and further to the US.

73. Jan Stożek, “Fidonet in Poland,” Pigułki, 6, 5 June 1991, http://ftp.icm.edu.pl/packages/ pigulki/pigulki6.pub.

74. Jacek Chrulski, "EĄczenie odległych komputerów [Connecting remote computers]", Komputer, July $1986: 38-39,43$.

75. "RozporzĄdzenie Ministra ŁĄczności z dnia 23 czerwca 1986 r. w sprawie ordynacji Telekomunikacyjnej [Resolution of Minister of Communications from 23 June 1984 on the statue of telecommunciations]," Dz.U. $1986 \mathrm{nr} 27$ poz. 135, http://isap.sejm.gov.pl.

76. Interview with Grzegorz Wiśniewski, chairman of the Department of Telecommunications Services in the Ministry of Communications, Marcin Przybyłowski, "Klucz do transmisji [A key to the transmission]," IKS. Informatyka Komputery Systemy, May $1986: 3$.

77. A homologation certificate, mostly used with communications technologies, proves that a particular model of an electronic device passed official technical tests and does not cause any interference with other communications systems.

78. Tadeusz Wilczek, “Sieć Fido [Fido network]," Komputer, July 1987 : 19.

79. Klaudiusz Dybowski, “Bzykomania [buzzmania]," Bajtek, Aug. 1991 : 44.

80. "The State of Telephone Communication," in Radio Free Europe/Radio Liberty Research Institute (RFE/RL Research Institute), Situation Report : Poland," 1 Sep. 1987, HU OSA 300-8-47, 25-28, http://www.osaarchivum.org/.

81. Interview with Prof. Władysław Majewski, Minister of Communications, "Komputery, łĄczcie sic̨ [Computers, connect together]," Komputer, April 1987 : 6-8, here 7.

82. Marianne van den Boomen, Sybille Lammes, Ann-Sophie Lehmann, Joost Raessens, and Mirko Tobias Schäfer, eds., Digital Material. Tracing New Media in Everyday Life and Technology (Amsterdam : Amsterdam University Press, 2009), 10. 
83. Interview with Prof. Władysław Majewski, Minister of Communications, "Komputery, łączcie się [See above]," : 7.

84. See footnote 33 .

\section{RÉSUMÉS}

Cet article étudie la façon dont les représentations du progrès scientifique, économique et social ont influencé le développement des réseaux informatiques de télécommunication en Pologne socialiste. L'auteur avance que les tentatives d'établir des réseaux de communication entre ordinateurs étaient interdépendantes de l'image de la communication électronique en tant que vecteur de progrès scientifique et économique. Tout en analysant le développement de systèmes particuliers de télécommunication tels les réseaux informatiques académiques et les ordinateurs privés, l'auteur démontre comment une telle représentation, juxtaposée à une vision de ce qu'on appelle le «champ de bataille électronique ", influença la compréhension publique des réseaux informatiques. Fondé sur des documents d'archives, des actes législatifs et des périodiques informatiques, cet article montre comment les informaticiens, les décideurs politiques et la communauté scientifique influencèrent la construction sociale des réseaux informatiques en tant que vecteurs de modernité et de développement social et scientifique.

This essay discusses how imageries of scientific, economic, and social progress influenced the development of computer-based telecommunication networks in state socialist Poland. The author argues that attempts at establishing communication networks between computers were interdependent with imageries of electronic communication as a vector of economic and scientific progress. While discussing the development of particular telecommunication systems such as academic computer networks and privately owned personal computer modems, the author shows how such imagery, juxtaposed with a vision of the so called "electronic battlefield," influenced public understanding of computer networks. Based on archival documents, legislative acts and computer periodicals, this article shows how computer professionals, policy makers, and the scientific community influenced the social construction of computer networks as vectors of modernity and social and scientific development.

\section{AUTEUR}

\section{PATRYK WASIAK}

Institute for Cultural Studies, University of Wrocław, Poland, patrykwasiak@gmail.com EN 